\title{
Öz
}

\section{Serkan OTACIOĞLU1}

Ses değişimi, buluğ (püberte) çağındaki çocuklarda ses eğitimi açısından ileriki yaşlardaki konuşma ve şarkı söylemedeki başarıları için son derece önemli ve dikkat gerektiren bir konudur. Dünyada pek çok çalışma bu konu üzerinde yoğunlaşmaktadır. Ancak ülkemizde üzerinde fazlaca çalışma yapılması gereken bir konudur. Çocuk sesleri ve mutasyon sırasındaki değișikliklerin ileriki yaşlarda etkisinin büyük olduğu gözlemlenmektedir. Bu sebepler yüzünden mutasyon belirtileri ve aşamaları incelenerek ergen çocukları mutasyon öncesi (premutasyon), mutasyon ve mutasyon sonrasinda (postmutasyon) nasıl bir ses eğitimi alması gerektiği ve söz konusu yaş çocuklarının hali hazırda aldığı eğitimin incelenip, yaşanan sorunların ve tartışmaların incelenerek çözüm önerileri sunmak ve konuya katkı sağlamak amaçlanmıștır.

Anahtar Kelimeler: mutasyon (ses değiş̧imi), ergen sesleri, ergen sesi eğitimi, Ses değişiminde ses sınırları

\section{VOICE CHANGING IN ADOLESCENT VOICES AND VOICE TRAINING}

ABSTRACT
Voice changes of puberty for highly-age children voice education in future years in terms of speaking and success in singing and an important issue that requires attention. A lot of work is focused on these issues in the world. However, more work needs to be done on an issue in our country. It is that the effect is greater in future years of changes and mutations during children's voices. For this reason, due to mutations symptoms and stages of examining adolescent children premutations, mutations and postmutations that kind of a sound education should take and examined the training received in the ready state of children that age, examining the experienced problems and discussions to provide solutions and subject aimed to contributed.

Keywords: Voice mutation, Adolescent voices, Adolescent voices training, Adolescent vocal range

\section{Giriş}

Ses eğitimi, bireylere sesini konuşurken ve şarkı söylerken anatomik ve fizyolojik yapı özelliklerine uygun olarak kullanabilmesi için gereken davranışların kazandırıldığı, önceden saptanmış ilke ve

\footnotetext{
${ }^{1}$ Marmara Üniversitesi Atatürk Eğitim Fakültesi GSEB Müzik Eğitimi Anabilim Dalı. E mail: sotacioglu@marmara.edu.tr.
} 
yöntemlerle planlanan hedeflere yönelik olarak uygulanan, planlı programlı bir süreçtir (Töreyin, 2008).

Müzik dersleri ilköğretim 2. ve 3 . kademede ve liselerde müzik dersleri genellikle şarkı söyleme ve koro eğitimi kapsamında müzik öğretmenleri tarafından verilir.

Ses eğitiminin amaçlarını, Töreyin'in (2008) sıraladığı gibi:

- Ses değişim/gelişim döneminin (mutasyon) özelliklerine uygun olarak

- Bulunduğu yaș ve ses grubunun özellikleri ile anatomik yapısına uygun ve doğru perdelerde

- Bulunduğu yaş ve ses özelliklerine uygun olarak konuşma ve şarkı söylemede doğru ses üretip kullanmasına yönelik davranışları kazandırmaktır olarak özetlersek sürekli vurgulanan

- Ses değişiminin özelliklerine göre

- Yaş grubuna göre

- Ses grubuna göre

- Yaşa göre terimleri geneli anlatsa bile her terim aslında mutasyon konusunda dikkatli olmayı anlatmaya yönelik tanımlardır.

Öyle ise tüm bu değişim dönemlerinde ses eğitimi de son derece bilinçli ve dikkatli yapılmalıdır ki ses yetişkin sesine sağlıklı geçebilsin ve gerçek profesyonel eğitimi yapabilecek sağlıkta olabilsin.

\section{Mutasyon}

Ergenlik dönemi, diğer bir adıyla "adolesan çağı", biyolojik, psikolojik, zihinsel ve sosyal açıdan bir gelişme ve olgunlaşmanın yer aldığı çocukluktan erişkinliğe geçiş dönemidir (Yavuzer, 2001: 262).

Başlangıçta ses değişimi (mutasyon) tanımını yapmak gerekmektedir. Mutasyonu genel olarak şu şekilde tanımlamak mümkündür.

Ses hayat boyu değişmektedir. Bireyin dilbilimsel ve iletişimsel gereksinimlerine uyumlu hızlı geçici değiş̧imler, konuşma yaşamımız boyunca yavaş yavaş değişir. Değişimlerin çoğu çok yavaş olur. Ancak bazılarının, özellikle erkek çocukların çocuk sesinden olgun erkek sesine geçişi gibi dramatik etkileri olabilir.

Hormonal gelişmeye bağlı olarak, özellikle erkek çocuklarda daha belirgin olmak üzere, buluğ çağında oluşan anatomik ve fizyolojik değişimlerden kaynaklı ses değişimidir. 


\section{Mutasyon belirtileri}

Mutasyon sırasında yaşanan değisşiklikler ve yapılan araştırmalardan bazılarını incelemek bize fikir verecektir.

Mutasyon sırasında larenks kıkırdakları büyür ve tiroid kıkırdak șekil değiştirir. Yuvarlak görünümünü kaybederek öne doğru bir çıkıntı oluşturur.

Ses telleri erkeklerde $1 \mathrm{~cm}$ kız çocuklarda 3-4 mm kadar uzar ve genişlik kazanır. Erkeklerde ses tellerindeki kas dokusunun bağ dokuya oranı daha fazladır. Kızlarda tam tersidir (Cevanşir ve Gürel, 1982).

Mutasyon dönemi klinik bulgularl; ses tellerinde hiperemi, fonasyon sırasında mutasyon üçgeni olarak bilinen glottis açıklı̆̆, mutasyonun akustik belirtileri ise sesin falset ve göğüs registerleri arasında gidip gelmesi, kırılması, ton tutma güçlügü, fazla hava kaybı, tremolo v.b. dir (Cevanşir ve Gürel,1982).

Fizyolojik olarak, yüzdeki değişimler, larenksin aşağıya inmesi (rezonatör bölgelerin büyümesi), göğüs duvarının genişlemesi (vital kapasitenin artması) gibi çok etken ses değişiminin nedenlerindendir.

Mutasyon sırasında erkeklerin çocukların sesi yalnızca genişlemez aynı zamanda bir oktav alçalır. Erkek seslerinin, kadınlardan bir oktav aşağıda duyulmasının nedeni budur.

Rezonatör bölgelerde bu süreç içerisinde eş zamanlı olarak gelişme gösterir. Kafatası ve yüz değişmiş bademcikler geri çekilmiştir. Orta Farenks büyümüştür. Burun son formunu alır ve nazal boşluklar, az veya çok ses kalitesinde etkilidirler.

Larenks büyümesindeki ani değişim beraberinde aynı oranda kas güçlenmesini gerektirir. Larenksin değişik bölümlerinde çeşitli büyüme oranları daha önce yerleşmiş olan kas fonksiyonlarını zorlaştırır. Bu dengesizlik ve ani değişim sırasında fonasyon güvensiz ve zor kontrol edilir bir duruma gelir.

Çocuklarda larenks yetişkin larenksinden anatomik olarak sadece küçük değil, aynı zamanda yapısı ve işlevi açısından da farklılık göstermektedir. Bu farklılıklar incelendiğinde ses yolunun çocuklarda kısa ve huni şeklinde olduğu, yeni doğan larenksinin boyunda yüksek konumda yani C3-C4 vertebra hizasında olduğu ve yaș ilerledikçe boyunda aşağı doğru indiği görülmektedir. Kıkırdak yapılar çocuklarda yumuşak ve esnek bir yapıya sahiptir.

Vokal kordlar, çocuklarda kısa ve daha az kas kütlesine sahiptir. Mukozal tabakalar daha ince ve vokal ligaman yoktur. Okul öncesi yıllarda vokal ligamen farklılaşmaya başlar ve ergenlik 
döneminde çift katmanlı yapısına kavuşur. Çocukluk dönemi boyunca larenks de vücuttaki diğer gelişmelere paralel olarak gelişir. Larenksin boyutları arttıkça temel frekansta da değişiklikler olmaktadır. Ağlamanın temel frekansı doğumda $500 \mathrm{~Hz}, 7$ yaşında $286,5 \mathrm{~Hz}, 8$ yaşında 275,8 Hz'dir. Çocuk ve yetişkinler arasında sadece temel frekans açısından değil, rezonans, perde, ses aralığı gibi ses parametreleri açısından da farklılıklar bulunmaktadır. Çocukların ses aralığı yetişkinlerden oldukça azdır. Çocuklar genellikle ses üretimine sert bir şekilde başlamakta; yetişkinler ise yumuşak fonasyon gerçekleştirmektedir (Özkan ve Demirhan, 2014).

Baken ve Orlikoffun ölçümlerine göre fonasyon süreleri yetişkin erkekte 20 sn, yetişkin kadında 15 sn, çocuklarda ise $10 \mathrm{sn}$ civarındadır (Baken and Orlikoff, 2000).

Weiss (1950) a göre mutasyon sırasında göğüs kafesinin çevresi ve boyu uzar. Bu da nefes kapasitesinde önemli bir artış oluşturur. Boyundaki uzama ve genişleme ise larenksin daha aşağıda konumlanmasını ve bu yüzden daha uzun ve geniş bir farenks oluşumuna neden olduğunu bu sayede de ses renginde değişim yaşandığını belirtir.

Mutasyon sırasında larenks gelişimini öne ve arkaya doğru olduğunu bu yüzdende ses tellerinin bir cm kadar uzadığını belirtir. Kızlarda olan gelişimin ise enine değil boyuna olduğunu söyler.

Mutasyon ile yaşanan fiziksel gelişmeler yüzünden erkeklerde ses aralığı yaklaşık bir oktav aşağıya inerken kızlarda ise 2-3 ses aşağıya inmesi söz konusudur.

Weiss'a göre; değişim önce ses sınırının altında bir kalınlaşma olurken üst sesler sabittir. Ardından değişim sırasında tiz sesler gidip gelen bir hal alır ve kaybolmaya başlar ve yeni kalın sesler kalıcı hale gelmeye başlar. Son aşamada ise Kalın sesler kalıcı hale geldikten sonra yeni sesin üst sesleri de kalıcı hale gelir.

15-16 yaşlarda bittiği ön görülen sesteki değișimin son aşamasının 2-3 yıl daha devam edebileceği düşünülmektedir. Bu yüzden de 18-19 yaşlarına kadar erkek çocukların ses türlerini sınıflandırmanın ve ciddi ses çalışmalarının yapılmasının çok büyük yanlış olacağı düşünülmektedir.

Değişim öncesini 10-12 yaşları arası olarak düşünürsek, şarkı sesi parlak bir soprano gibidir ve konuşma tonu orta do civarındadır.

Değişim sırasında (12-14) yaşları arasında şarkı sesi elastikliğini kaybeder ve kontrol etmede güçlük çekilmektedir. Konuşma tonu da 2-3 tam ses pesleşmiştir. 
Değişim sonrasında (14-16/17) ise konuşma sesi mi/re ye kadar inmiştir. Şarkı sesi ise parlaklığını kaybetmiş ancak yetişkin sesi tınısı da içermemektedir.17-18 yaşlarında yetişkin renginin oluştuğu görülür.

Kızlarda mutasyon daha az belirgindir. Bunun nedeni de larenks büyümesindeki değişik değerlerdir. Erkeklerde bir oktav aşağıya inerken kızlarda yaklaşık 3 ton kadar iner.

Kızlarda değişikliğin belirtileri; ses hacminin artması ve ses renginin değișmesi, yetersiz nefes veya çatlamalar ses tonunu ayarlamadaki zorluk ve istemsiz ses düşüşleridir.

T. Hacki , S. Heitmüller (1999) in 4-12 yaş arası sağlıklı sese sahip 180 çocukla yaptığı araştırmada çocukların konuşma sesi, bağırma sesi ve şarkı söyleme sesleri ayrı ayrı incelenmiştir. Sonuçlar yaşların büyümesi ile sesteki yeteneklerin geliștiğini göstermektedir.

Ayrıca araştırmada sesindeki perde düşüşü erkeklerde 8 ile 9 yaşları arasında kızlarda ise 7 ile 8 yaşları arasında görülmektedir. Konuşmadaki konuşma şiddetinin azalması ve şarkı söylemedeki yumuşaklığı ve en az ses yorgunluğunu edinmek yine erkeklerde 8 ile 9 yaşlarında kızlarda ise 7 ile 8 yaşlarında kazanmaktadırlar. Ergenlik sonrası sesin oluşması ise iki cins içinde 10 yaşını bulmaktadır. Premutasyon kizlarda erkeklerden bir yıl önce başlamaktadır.

Willis ve Kenny 2011 yılında 12-13 yaşlarında mutasyon dönemindeki $20 \mathrm{kız}$ korist ile yaptıkları araştırmada konuşma sesi, ses genişliği ve register geçişlerini izlemişlerdir. Sonuç olarak ulaştıkları ses genişliklerini aşağıdaki gibi belirtmişler;-Tessitura genişliklerini ise Cornellius Reid'in (1983) "in the pitch range a singer is capable of producing with the greatest ease regardless of technical limitations"'adlı çalışmasında belirtiği gibi kabul etmişlerdir (Willis ve Kenny, 2011). 


\begin{tabular}{|c|c|c|}
\hline & Ses Genişliği & Tessitura \\
\hline Değișimden önce: & $233-698 \mathrm{~Hz}[\mathrm{~B} 3-\mathrm{F} 5]$ & {$[\mathrm{D} 4-\mathrm{D} 5]$} \\
\hline Değişim bașlangıcı: & $220-784 \mathrm{~Hz}[\mathrm{A3}-\mathrm{G} 5]$ & {$[\mathrm{D} 4-\mathrm{D} 5]$} \\
\hline Değișimin zirvesi: & $220-698 \mathrm{~Hz}[\mathrm{~A} 3-\mathrm{F} 5]$ & {$[\mathrm{B} 3-\mathrm{C} 5]$} \\
\hline Değișim sonrası: & $220-880 \mathrm{~Hz}[\mathrm{A3}-\mathrm{A} 5]$ & {$[\mathrm{A3}-\mathrm{G} 5]$} \\
\hline
\end{tabular}

Tablo 1:

12-13 yaş 20 korist kız ile yapılan ses genişiliği ve tessitura tablosu.

Willis ve Kenny mutasyonu tanımlayan şöyle bir formül getirmişlerdir:

1. Konuşma tonunda temel frekans aşağıya doğru inecektir.

2. Ses genişliği Vokal gelişime bağlı olarak önce daralan sonra genişleyen bir yelpaze oluşur.

3. Fiziksel gelişime bağlı olarak seste kırılmalar olur.

Özetle mutasyon sırasında özellikle erkeklerde, testesteron hormonu birçok önemli değişikliklere sebep olur. Bu yüzden kadınlara göre daha hızlı büyüyen larenks, ses tellerinin genişlemesine ve kalınlaşmasına neden olur. Uzun ses tellerine sahip olmak doğal olarak temel frekansın çoğalmasına neden olur. Çocuksu ses aralığından yetişkin sese geçişte larenksin büyümesiyle ses alçalır. Konuşma tonunun alçalmasına ek olarak ses bu süreçte boğuk ve zayıf duyulur. Erkeklerde ses aralığı sadece genişlemez aynı zamanda 1 oktav alçalır.

Erkeklerdeki en önemli belirti, yeni gelişen erkek sesi ile önceki çocuk sesi arasındaki ani değişimdir. Bu güvenilir olmayan sese "ses kırılması" denir.

Larenksin büyümesindeki ani değişim beraberinde aynı oranda kas güçlenmesini de gerektirir. Larenksin değişik bölümlerinde çeşitli büyüme oranları daha önce yerleşmiş olan kas fonksiyonlarını zorlaștırır. Bu dengesizlik ve ani değişim sırasında fonasyon güvensiz ve zor kontrol edilir durumdadır.

Erkek sesinde konuşma sesinin değişimi 3-6 ay gibi bir sürede tamamlanmasına rağmen şarkı sesi değişimi uzun bir süreçtir. Birçok araştırmacının sistemli ve ciddi bir ses eğitimine 18 yaşından önce başlanmamasını önermesinin nedeni budur. Bu cümle araştırmanın temel tartışma konusunun dayandığı cümle olarak ta düşünebiliriz. 


\section{Ergen sesi eğitimi}

Mutasyon sırasında kızlarda bazı zorluklar içerirken nispeten erkeklere göre daha kolay geçer. Erkeklerde ise gerçekten zorlu bir süreçtir ve özel dikkat ve eğitim gerektirir. Bu da eğitimcilere ve özellikle koro şeflerine özel bir sorumluluk yükler.

$\mathrm{Bu}$ yüzden de araştırmalar özellikle erkek ergenlerin ses değişimi üzerine yoğunlaşmıştır. Manuel Garcia bu kriz durumu hakkında, sesi doğasına bırakmayı ve bireysel özelliklere göre davranmayı önermiştir (Garcia, 1970).

Bu dönemde değişim bireylere göre değişiklik gösterebilir. Bu yüzden her ergen için gösterdiği değiş̧im ve kişisel özelliklerine göre hareket etmek doğru olacaktır. Bu da eğitimcinin yeteneğine ve bilgi birikimine ve dikkatine doğrudan bağlı olacaktır.

Bazı eğitimciler bu dönemde bu kırılgan sesle çalışma hakkında bu dönem geçene kadar şarkı söylemeyi bırakmak gerektiğini savunurlar. Çünkü bu dönemde yapılan çalışmaların ses organına zarar vereceğini ve kalıcı hasarlar oluşturacağını belirtirler.

Ancak günümüzde bu yöntem çok ta kabul görmemektedir. Bunun yerine çok ciddi ve zorlayıcı ses çalışmalarından kaçınmak tavsiye edilmektedir. Yapılan bir uygulamada seste belli bazı gerilemeler ve yetersizlikler olursa israr etmeden yeni yöntemler denemek ve sesi aşırılıktan korumak, zorlamadan çalıştırmak çok önemlidir. Aksi takdirde ergeni hiç ses kullanmamaya itmek onda güvensizlik yaratacak ve başarısız olma korkusu ile birlikte şarkı söylemeyi bırakma ve soğuma gibi sonuçlar yaratacaktır.

Garcia ve destekçilerinde yaygın kanı mutasyon döneminde 3 yll kadar sesin dinlendirilmesi şeklinde olmuştur. $\mathrm{Bu}$ teori Avrupa'nın büyük bölümünde ve özellikle İngiltere'de Kilise koroları(erkek koroları) ve okullarda kabul görüp uygulanmıştır.

1956 yllinda McKenzie "Training the boy's changing voice" kitabı ile yeni bir bakış getirmiştir. Ona göre mutasyondaki ergenler ayrı olarak çalıştırılmalıdır.

McKenzie değişimden önceki erkek sesini soprano olarak tanımlamıştır. Ancak mutasyon başladığında bu yavaş yavaş alçalan sesi ise soprano II olarak isimlendirmiştir. Sonrasında ise alto ve daha sonra tenor olarak sınıflandırmıştır. Bu sıralama gözetilerek çalıştırmayı önermiştir. Ayrıca bu sesin ne bir çocuk sesi ne de bir erkek sesi kalitesinde olmayacağını eklemiştir (McKenzie, 1956). 
"Alto-tenor" dediği bu modelde ses genişliğini (f-c2) arasında kabul edip çalıştırmayı önermiştir. Bu model daha çok Amerika da kabul görmüștür.

Amerika'da o zamanlarda okullarda kızlarla erkekleri ayırarak seslerine göre çalıştırmak ve korolarda kız korosu tercihleri zaten mevcuttu.

1970' lerde Dr. Irvin Cooper yeni bir model geliştirmiştir. (Nota Cambiata=değişen nota) teriminden esinlenerek (Changing voice $=$ Değișen ses) anlamında "Kambiata Konsept" denen bu model McKenzie'nin éalto-tenor" modeli ile benzerlikler göstermektedir.

Cooper değişmemiş soprano ses aralığını (b-f2) aralığında ilk değiş̧imde kambiata sesin aralığını (f-c2) ikinci değişimi (B-f1) ve değişim sonrasını (F-c1) olarak gösteren dört aşamalı modeli sunmuştur. (Cooper, 1950)

Bir diğer teori ise John Cooksey tarafından geliştirilmiștir. Cooksey'in cambiata konseptinde ses değișimi beş aşamalı model ile anlatılmıştır.

1. Aşama I: Değişim Öncesi

2. Așama II: Erken Değişim

3. Aşama III: Değişim zirvesi

4. Așama IV: Değişim sonrası dönem

5. Aşama V: Yetişkinlik safhası başlangıcı

(Cookksey, 1977)

Buna Karşı Frank ve Sparber'in da kullandığı ve genel kabul gören üç aşamalı model daha anlaşılır olacaktır inancındayız.

1. Premutasyon( Mutasyon öncesi)

2. Mutasyon (Ses değişimi)

3. Postmutasyon (Mutasyon sonrasi)

Frank ve Sparber'e göre erkek çocuk seslerinin ses değişiminin her aşamasında şu ses genişliklerini belirtmişlerdir.

1. Premutasyon(mutasyon öncesi): f-g2

2. Mutasyon(Ses değişimi): c-e1

3. Postmutasyon(mutasyon sonrası): g-c1

(Frank ve Sparber 1980)

Genellikle bu yaş (9-18) grubunda sesin uygunsuz kullanımı ya da eğitim eksikliği, ses problemleri ya da fonksiyonel bozukluklara yol açmaktadır. Üstelik yanlış kullanımdan kaynaklı ses hasarları için çok az sayıda ergen, ses gelişimi ve potansiyel ses hakkında ilgili yeterli teorik bilgiye sahiptir. Ayrıca birçok ergen koşullara ve bu 
yeni yaşam aşamasının taleplerine uyum sağlamak için yanlış şan teknikleri kullanmak zorunda kalmaktadır. Kendini kanıtlama ve sesindeki değişimin üstesinden gelmek gibi duygularla, cüretkâr ve eforlu ses kullanımına yatkındırlar.

Konu hakkında tartıșma bu seslerin nasıl eğitileceği, kimler tarafında eğitileceği, eğitimi verenlerin hangi donanımda olacağı ve hangi yöntemlerin kullanacağ yoğunlaşmaktadır.

Çağdaş eğitim, bilim, sanat ve teknik alanlarının üçünü de kapsayan bir çerçevede düzenlenip uygulanır. Müzik eğitimi sanat eğitiminin en önemli dallarından biridir. Bireye istendik olarak müziksel davranıșlar kazandırma veya müziksel davranıșlarında değişiklikler oluşturma süreci, müzik eğitimidir. Bu süreçte daha çok eğitim gören bireyin (çocuğun-öğrencinin) kendi müziksel yaşantısı temel alınır, bu temelden yola çıkarak belirli amaçlar doğrultusunda planlı ve yöntemli bir yol izlenir ve bu yolla belirli hedeflere erişilir. Müzik eğitimi yoluyla birey ile çevresi, özellikle müziksel çevresi arasındaki iletişim ve etkileșimin daha sağlıklı, daha düzenli, daha etkili ve daha verimli olması beklenir (Uçan, 1994).

Ses eğitimi, sadece soyut bir yaklaşımla, duyumlara bağlı olarak örneklendirme-yansılama yöntemiyle değil, aynı zamanda ses organlarının fizyolojisi ve işlevlerine ilişkin konularda bilgilendirme ile de pekiştirilerek, genel amaçlar doğrultusunda yapılmalıdır (Çevik, 1999).

Güzel Sanatlar ve Spor Liseleri ses eğitimine yönelik temel davranışların kazandırıldığı orta öğretim kurumları olarak 15-18 yaş arası çocukların temel ses eğitimine yönelik çabaları içermektedir (İstanbullu-Ayçimen, 2013)

Güzel Sanatlar ve Spor Liseleri ses eğitimi dersi öğretim programında ise "bireysel ses eğitimi dersi; Türkçeyi doğru kullanma, solunum tekniklerini uygulama, sesini tanıma ve doğruetkili kullanma, ses eğitimi tekniklerine uygun olarak halk türkülerini, okul şarkılarını, Türk ve Dünya ses müziğinden değişik eserlerin seslendirilmesini kapsamaktadır. Güzel Sanatlar ve Spor Liselerinde öğrenim gören öğrencilere; Bireysel ses eğitimi dersi aracılığıyla mutasyon dönemi özellikleri de göz ardı edilmeden, doğru ve sağlıklı ses üreterek, güzel ve etkili konuşma ve şarkı söyleme, sesini doğru kullanma ve koruma alışkanlığı kazandırılması amaçlanmaktadır" ifadesi geçmektedir (MEB, 2008:9).

Öncelikle bu yaş (ergenlik dönemindeki) aralığında çocuklara eğitim veren öğretmenlerin mesleki eğitiminde konu hakkında 
bilgilendirilmesi gerekmektedir. Bu yüzden eğitim fakülteleri Müzik eğitimi bölümlerinde eğitim gören öğretmen adayların ses eğitimi ve koro derslerinde kendi seslerini eğitme ve gerekli yeterliliği sağlamak amaçlanarak eğitildiği düşünülmelidir. Hem ses eğitimi vermek hem de özel olarak mutasyon çağındaki sesleri eğitmek için teorik olarak verilecek ses ve solunum fizyolojisini ve mutasyon çağındaki seslerin eğitimi hakkında bilgileri içeren teorik bir ders görmeleri kanımca zorunluluktur.

Ayrıca solfej öğretmenlerinin ve koro șeflerinin ses konusunda bilgili, donanımlı ve sorumlulukları gereği çok dikkatli olmaları gereklidir. Solfej derslerinde kullanılan parçaların ses aralıklarına dikkat ederek, her çocuğun ses sınırlarına göre parçalar ile çalışmaları gerekmektedir.

Gerek solfej gerekse koro öğretmenlerinin çağdaş ses eğitimi kurallarını dikkate almamaları halinde, çoğunluğu henüz mutasyon dönemini yaşamakta olan öğrencilerin gelecekteki ses performansını negatif yönde etkileyecek kusurlara yol açılması kaçınılmaz olur (Okatan. 1996).

Ses eğitiminin, Güzel Sanatlar ve Spor Liseleri'nde 14-18 yaş grubundaki öğrencilerin, sanatsal gelişimlerine önemli katkıda bulunduğu düşünülebilir. Güzel Sanatlar ve Spor Liselerinin amaçları doğrultusunda, ders olarak okutulan Bireysel ses eğitimi' nin bu amaçlara yönelik bir yönlendirme sağladığı, öğrencinin ses değişimi, gelişimi ve eğitimi açısından büyük önem taşıdığı söylenebilir (Tanrı̈ven ve Temiz, 2012).

\section{Tartışma}

Eldeki araştırma bireysel ses eğitimi ve toplu ses eğitimi sırasında ergenlik süresince oluşan ses değişiminin gelişimi ve eğitimi açısından süregelen tartışmalardan bazıları aşağıdaki konulara dikkat çekmiştir.

İstanbullu ve Ayçimen'in araştırmasındaki öğrenci şikâyetlerinin bazıları çok dikkat çekicidir. Araştırmada 9.sınıfta Bireysel Ses Eğitimi ve Koro Eğitimi dersinin olmaması nedeniyle birçok sorun yaşadıklarını ifade etmişlerdir. Doğru nefes alma, doğru ses üretme ve birlikte söyleme alıșkanlığı edinememelerinden dolayı Müziksel İşitme Okuma(MİO)dersine yönelik solfej okuma dersinden sonra ses tellerinin çok yorgun olduğunu ve acı hissettiklerini, Bireysel Ses Eğitimi dersinin 9. sınıftan itibaren almak istediklerini 9. sinıfta edinilecek doğru ses ve nefes teknikleriyle müziksel okumaya 
daha bilinçli bir başlangıç yapabileceklerini, sesi ve nefesi doğru kullanarak, bu kazanımı, eğitimlerinin diğer alanlarına da aktarabileceklerini Bireysel Ses Eğitimi dersine 12. Sınıfta başlamış olmanın çok geç olduğunu, şimdiye kadar Koro Eğitimi derslerinde kendilerince oluşturmuş oldukları ses kullanım tekniklerini değiştirmenin çok zor olduğunu, 12. sınıfa kadar seslerini bilinçsiz kullandıklarından dolayı çok yormuş ve yıpratmış olduklarını hatta bazı öğrencilerin ses tellerinde nodül oluşumları olduğunun doktor tarafından teşhis edilmiş olduğunu belirtirler. (İstanbullu-Ayçimen, 2013

Ayrıca araştırma sonucunda öneri olarak sunulan, Güzel Sanatlar ve Spor Liseleri'nde öğrenim gören öğrencilerin ses eğitimlerinde, mutasyon dönemlerinin en sağlıklı biçimde nasıl geçirilebileceği konusunda verilecek ciddi bir eğitimin bu liselerdeki ses eğitiminde öncelikli amaç olması gerektiği düşünülmektedir. Bu düşünce doğrultusunda Güzel Sanatlar ve Spor Liseleri'nde, Bireysel Ses Eğitimi ve Koro dersi veren öğretmenlerin çeşitli hizmet içi seminer ve kurslarla yeterliliklerinin arttırılması önerilmektedir. (İstanbullu-Ayçimen, 2013)

Önermesi son derece doğru bulunmakta ayrıca bu eğitimlere MİO dersi öğretmenlerinin de katılması öğrencilerin ses sağlığı açısından çok önemli görülmektedir.

Mutasyon sırasında kızlarda bazı zorluklar içerirken nispeten erkeklere göre daha kolay geçer. Erkeklerde ise gerçekten zorlu bir süreçtir ve özel dikkat ve eğitim gerektirir. Bu da eğitimcilere ve özellikle koro şeflerine özel bir sorumluluk yükler.

Bu dönemde değiş̧im bireylere göre değiş̧iklik gösterebilir. Bu yüzden her ergen için gösterdiği değişim ve kişisel özelliklerine göre hareket etmek doğru olacaktır. Bu da eğitimcinin yeteneğine ve bilgi birikimine ve dikkatine doğrudan bağlı olacaktır.

$\mathrm{Bu}$ yüzden özellikle toplu ses eğitimi yapan müzik öğretmenleri ve koro şeflerinin mutasyon sürecindeki çocukları tek tek takip etmesi gerekmektedir. Her dönemde onları şarkı söylemenin güzelliği konusunda teşvik ederken bir yandan da gerekirse grup grup gerekirse bireysel olarak çalışmaya tabi tutarak ve ses aralıklarına ve ses kullanımlarına dikkat ederek doğru davranışları kazandırma ve ses sağlıklarını koruma yolunda hareket etmelidirler.

Her şeyden önce korolarında söyletecekleri çocukları en başta tek tek inceleyerek seslerini doğru belirleyip, bireysel değişimlerini fark etmeleri son derece önemlidir. 
Koroda ses eğitimi toplu ya da grupsal olarak yapılır. Gerekli görüldügünde kişisel ses sorunlarını gidermek için bireysel olarak da yapılabilir (Yiğit, 2006).

Sonraki adım ise repertuar doğru oluşturma aşamasıdır. Söyletmeyi çok arzuladığı parçaları değil elindeki bireylerin ses yeterliliklerine göre repertuar seçmeye özen göstermelidirler. Unutulmamalıdır ki, profesyonel ses eğitimine kızlar için 16 erkekler için 18 yaşından sonra başlanmalıdır. Bu saptama ortadayken Ortaokul ve lise çağındaki çocuklara klasik müzik repertuarının en zor eserlerini söyletip gururlanan öğretmenlerin aslında ne kadar büyük yanlış içinde olduklarının farkında olmaları gerekmektedir.

Türkiye'deki örgün eğitimin temeli olan ilköğretim kurumlarında çocuğu müzik sevgi ve bilgileriyle donanımlı olarak yetiştirmek, dalında yeterli ve iyi yetişmiş, nitelikli müzik öğretmenleri yetiştirildiğinde mümkün olacaktır (Töreyin, 1997).

Donanımlı eğitimciler ile üniversite çağına gelmiş özellikle müzik eğitimi bölümleri ve konservatuar şan bölümlerine girmek isteyen gençlerin sesleri yıpranmamış, bozulmamış ve sağlıklı olacaktır. Bu da üniversitelerde mesleki eğitim veren bölümler ve hayallerinde şarkıcılık ya da müzik eğitimciliği olan genç bireyler için hayati önemde bir konudur.

Ses kullanımı sırasında en çok yapılan yanlışlıklar şunlardır:

- Normal ses sınırlarını aşma

- Çocuk yaşına uymayan ses dinamizmi(çok kuvvetli söyleme ve bağırma)

- Solunumu iterek kullanma(forse solunum)

- Uzun süreli koro çalışmaları

- Ses türünü ayırmada yapılan yanlışlıklar

- Bağırarak konuşma

- İyi telaffuz etmeme (Cevanşir-Gürel, 1982)

\section{Öneriler}

Yukarıdaki literatür ve bilgiler doğrultusunda verilen öneriler aşağıda sıralanmıștır:

- Bu yüzden uygun ses eğitimi davranışlarına ulaşmak için, yumuşak fonasyon kullanımını teşvik etmek ve sesin kullanım alanının muatsyon aşamalarına uygun olarak dikkatle sınırlandırılması larenksteki gerilimlerin önlenmesi ve eforlu kullanımın zararlarını önlemekte en faydalı yöntem olacaktır. 
- Çocuk ve Ergen seslerde çalışma süreleri de ayrı bir öncelik konumuzdur. Bu çalışmaların uzun süreler almayan ve zorlayıcı olamayan çalışmalar olması eğitimci tarafından dikkatle planlanmalıdır. Ergen seslerinde bireysel çalışmalar ya da koro çalışmalarında mutlaka bir ses sınıflandırması her çocuk için yapılmalı ve mutasyonun her aşaması dikkatle gözlenmelidir. Değișime göre korodaki yeri söylediği parti ve ses aralıkları ayarlanmalıdır.

- Bir koro şefi "korosunda ses eğitimini gerçekleştirebilmelidir" (Çevik,1999:143)Bu yüzden bir koro şefinin de müzikal birikimin yanında, en az bir ses eğitimcisi kadar anatomi ve fizyoloji hakkında bilgisi olmalıdır. Bu yüzden eğitim fakültelerinde ses eğitimi ve koro șefliği alanında ilerlemek isteyen her öğrenciye lisans döneminde ses ve solumun fizyolojisi dersleri verilmelidir. Uzmanlaşmaya başladıkları yüksek lisans ve doktora eğitimlerinde ise mutlaka bu dersin ileri düzeyi "ses pedagojisi" gibi dersler zorunlu olarak verilmelidir.

- Güzel Sanatlar ve Spor Liseleri'nde, Bireysel Ses Eğitimi ve Koro dersi veren öğretmenlerin çeşitli hizmet içi seminer ve kurslarla yeterliliklerinin arttırılması önerilmektedir (İstanbullu-Ayçimen, 2013). Önermesi son derece doğru bulunmakta ayrıca bu eğitimlere MíO dersi öğretmenlerinin de katılması öğrencilerin ses sağlığı açısından çok önemli görülmektedir.

- Koro da söylemenin sanıldığının aksine belli başlı teknik birikimler gerektiği düşünülürse öncelikle toplu söyleme ile başlayıp ilerleyen yıllarda bireysel söyleme üzerine yoğunlaşan eğitimi anlayışının yerine öncelikli bireysel ses eğitimi dersleri ile başlayıp bazı temel bilgiler edindirildikten sonra toplu söylemeye geçilmesi. Ya da en azından eş zamanlı bir eğitimim sürdürülmesi.

- Solfej derslerinde, kullanılan materyallerin yaş gruplarına ve bu grupların seslerinin özelliklerine göre yeniden planlanmasi.

- $\mathrm{Bu}$ genel planlama yapılmadığı takdirde, eğitmenlerin solfej derslerinde kullanılan parçaların ses aralıklarına dikkat ederek, her çocuğun ses sınırlarına göre parçalar ile çalışmaları gerekmektedir. 
- Profesyonel olarak beceri gerektiren eserlerin bireysel ses eğitimi ya da koro derslerinde kullanılmaması. (kızlarda 16, erkeklerde 18 yaş öncesi profesyonel anlamda ses eğitimine başlanmamalıdır.)

- Koro ve bireysel ses eğitimi derslerinde belirli bir plan dâhilinde derslerin işlenişi için aşağıda sıralanan basamakları uygulamaya çalışmak:

1. Ses hijyeni ve fizyolojisi hakkında kısa bilgiler vererek bașlamak

2. Vücut esneme çalışmaları

3. Doğru duruş hakkında her öğrenciyi uyararak ve kontrol ederek doğru duruş (posture) alışkanlıklarını kazandırmak için kontrol

4. Doğru nefes kontrolleri yaparak yanlışların düzeltilmesi

5. Basit egzersizler yardımı ile forse solunum, duruş ve vücut esnekliğinin kontrolü

6. Ses üretiminde ses şiddeti ile ilgili bireysel kontrol ile fazla eforlu ve volümlü olan öğrencilerin ses şiddetlerinin kontrolü ile yumuşak fonasyon alışkanlığının edindirilmesi

7. Rezonans çalışmaları

8. Artikülasyon çalışmaları

9. Çalışılacak parçaların prozodik yapılarına uygun konuşma çalışmaları

10. Çok kısa süreli (20 dakikayı geçmeye) parça çalışmaları

11.Bütün kazanımların kontrolü

12. Bağırarak konuşan öğrencilerin konuşma alışkanlıklarının düzeltilmeye çalışılması için uyarılması ile dersi bitirmek.

- Bireysel ses eğitimi derslerinin 9. sınıfta başlaması toplu ses eğitiminin daha sonraki sınıflarda 10-11-12. sınıflarda başlaması ya da en azında eş zamanlı başlaması

\section{Kaynaklar}

BAKEN, R. \& ORLIKOFF, J. (2000). Normative data of female and males, http://www.unc.edu. 
$\overline{\text { CEVANŞİR, B.-GÜREL, G. (1982). Foniatri, sanal matbaacılık, İstanbul, }}$ S.58.

COOKKSEY, J. (1977). The development of a contemporary, Eclectic theory for the training and cultivation of the junior high school male changing voices. The Choral Journal.

COOPER. I., (1950) "The junior high school choral problem" Music Educators Journal 37, No. 2, s.20-21.

ÇEVIK. S. (1999). Koro eğitimi yönetimi ve teknikleri, Yurtrenkleri yayınevi, Ankara. s. 64, 143.

HACKI. T. and S. HEITMULLER, "Development of the child's voice: premutation, mutation", INT J PED O, 49, 1999, pp.141-144.

OKATAN. İ., (1996). Anadolu Güzel Sanatlar Liselerinde Ses Problemleri. M. Ü. Atatürk Eğitim Fakültesi Eğitim Bilimleri Dergisi, Sayl: 8 Sayfa, 167 -172.

REID. C. (1983). A Dictionary of Vocal Terminology. An Analysis. New York: Joseph Patelson Music House Ltd, 372.

SPARBER, M. \& FRANK, F. (1908). Die Mutations-Stimme im gesangUnterricht, Pan A.G. No:103, Zurich.

MEB, (2008). Bireysel Ses Eğitimi Dersi Ögrretim Programı. Ankara: Devlet Kitapları Müdürlüğü.

İSTANBULLU, S.- ÖZÇiMEN, A. Güzel Sanatlar ve Spor Liseleri Öğrencilerinin Bireysel Ses Eğitimi ve Koro Eğitimi Derslerinde Yaşadıkları Sorunların Ders Çizelgesi Açısından Değerlendirilmesi. İstanbullu, S. ve Özçimen, A. NWSAQualitative Studies, E0018, 8, (2), 1-11.

ÖZKAN, E. DEMIRHAN, E. (2014). Pediatrik ses bozuklukları ve ses terapisinin etkinliği, Kocaeli Tıp Dergisi 2014; 2:27-33 (Medical Journal of Kocaeli 2014; 2:27-33).

TANRIÖVEN. G. B. ve TEMIZ. E.,(2012). Güzel Sanatlar ve Spor Liselerinde bireysel ses eğitimi ders kitabının, öğrenci açısından işlevselliğinin incelenmesi, e-Journal of New World Sciences Academy, Volume: 7, Number: 1, s.11-20.

TÖREYIN, M. (1997). Türkiye'nin İlköğretim Kurumlarındaki "Müzik eğitimcisi Sorunu", Filarmoni Sanat, Ocak, Sayı.142. s.5.

TÖREYIN, M. (2008) Ses Eğitimi Temel kavramlar-ilkeler ve yöntemler, Sözkesen Matbaacllık, Ankara.

UÇAN, A. (1994). Müzik Eğitimi. SAY Yayınları, Ankara.

WEISS, D. A. (1950) The Pubertal Change of the Human Voice (Mutation). Folia Phoniatrica 1950;2. S.126-159. (DOI:10.1159/000262578) 
WILLIS, E. \& KENNT, D. (2011). Voice Training and Changing Weight-Are They Reflected in Speaking Fundamental Frequency, Voice Range, and Pitch Breaks of 13-Year-Old Girls? A Longitudinal Study. Journal of Voice, Vol. 25, No. 5, New South Wales, Australia.

YAVUZER, H., (2001). Çocuk Psikolojisi, (20. Baskı). İstanbul: Remzi Kitabevi.

YİĞìT, N. (2006). Koroda ses eğitimi çalışmalarının çocuk ses gelişiminde etkileri. Selcuk Universitesi Sosyal Bilimler Enstitüsü Dergisi, Vol: Issue:16, s. 778. 